\title{
PENGARUH PELATIHAN DAN MOTIVASI KERJA TERHADAP KINERJA KARYAWAN PADA KARYAWAN DIVISI PRODUKSI PT INDO-EXTRUSIONS- CIMAHI
}

\author{
Putri Febrima R Sianturi \\ Universitas Pendidikan Indonesia \\ putrifebrima11@gmail.com \\ Hari Mulyadi \\ Universitas Pendidikan Indonesia \\ harimulyadi@upi.edu
}

\begin{abstract}
ABSTRAK
Latar belakang penelitian ini adalah rendahnya kinerja karyawan. Hal tersebut ditandai dengan rendahnya kinerja karyawan yang ditandai dengan tidak tercapainya target perusahaan serta rendahnya penilaian kinerja karyawan. Belum optimalnya kinerja karyawan harus segera ditindak lanjuti. Mengingat peran dari kinerja yang sangat penting dan berpengaruh terhadap tercapainya tujuan perusahaan Pelatihan dan Motivasi kerja dijadikan suatu cara untuk meningkatkan kinerja karyawan.

Tujuan dari penelitian ini adalah untuk mengetahui gambaran Pelatihan Kerja, Motivasi kerja, Kinerja karyawan, Besarnya pengaruh pelatihan terhadap kinerja karyawan, Besarnya pengaruh motivasi kerja terhadap kinerja karyawan, Besarnya pengaruh pelatihan dan motivasi kerja terhadap kinerja karyawan.

Objek dalam penelitian ini adalah karyawan PT Indo-Extrusions di Cimahi. Variabel bebas (X) dalam penelitian ini adalah pelatihan dan motivasi kerja, serta variabel terikat (Y) yaitu kinerja karyawan. Jenis penelitian yang digunakan adalah deskriptif dan verifikatif. Metode yang digunakan dalam penelitian ini adalah metode explonatory survey dengan teknik sampel jenuh dengan jumlah sampel sebanyak 75 orang. Teknis analisis data yang digunakan dalam penelitian ini adalah regresi linear berganda, dengan bantuan program SPSS 21.0 for windows.

Hasil temuan dalam penelitian ini antara lain sebagai berikut: 1) pelatihan pada PT Indo-Extrusions dalam kategori tinggi, 2) motivasi kerja pada PT Indo-Extrusions juga dalam kategori tinggi, 3) kinerja karyawan PT Indo-Extrusions dalam kategori tinggi, 4) kinerja karyawan dipengaruhi secara positif oleh pelatihan dengan korelasinya sebesar 44,4\%, 5) kinerja karyawan dipengaruhi secara positif oleh motivasi kerja dengan korelasinya sebesar $52 \%, 6$ ) kinerja dipengaruhi secara positif oleh pelatihan dan motivasi kerja dengan koefisien determinasinya sebesar $87,7 \%$.
\end{abstract}

\section{Kata Kunci: Pelatihan Kerja, Motivasi Kerja, Kinerja Karyawan}

\section{PENDAHULUAN}

Era globalisasi telah banyak memberikan tekanan terhadap sebuah organisasi untuk terus meningkatkan kualitas sebuah organisasi. Peningkatan yang dilakukan tidak hanya mencakup keahlian individu akan tetapi meningkatkan seluruh aspek yang terdapat di dalam organisasi. Upaya peningkatan yang dapat dilakukan oleh perusahaan untuk dapat bersaing yaitu kinerja karyawan agar dapat secara optimal meningkatkan kinerja perusahaan itu sendiri.

Rendahnya kinerja karyawan dapat dilihat dari berbagai aspek antara lain tidak tercapainya target perusahaan, rendahnya penilaian kinerja karyawan serta rendahdanya tingkat kehadiran karyawan. Kinerja karyawan yang tinggi sangat dibutuhkan oleh perusahaan aluminium ekstrusi. Perusahaan yang bergerak dalam industri aluminium ekstrusi merupakan perusahaan yang bergerak dalam sektor produksi yang sangat bertumpu pada efisiensi dan keefektifan kerja karyawan. Oleh karena itu perusahaan yang bergerak pada industri aluminium ekstrusi sangat mengandalkan kualitas dan kinerja karyawan yang tinggi.

Industri aluminium ekstrusi adalah industri logam dasar terpenting selain industri tembaga serta besi dan baja yang dibutuhkan pada infrastruktur dan pendukung sektor industri lainnya. Sejak diresmikannya PT Indonesia Asahan Alumunium (Inalum) menjadi BUMN pada tanggal 19 Desember 2013, total produksi PT Inalum kini $100 \%$ digunakan untuk memenuhi kebutuhan alumunium dalam negeri yang sebelumnya hanya $40 \%$ dan sisanya untuk luar negeri. (Sumber: www.liputan6.com, diakses pukul 11.57 WIB, 16 Juli 2014). 
Industri aluminium ekstrusi mempunyai peluang bisnis yang cukup tinggi. Peluang ini dapat dilihat dari sedikitnya perusahaan yang memproduksi aluminium ekstrusi di Indonesia. Menurut data yang diperoleh dari Kementrian Perindustrian terdapat 4 perusahaan di Indonesia yang memproduksi aluminium ekstrusi. PT IndoExtrusions merupakan salah satu perusahaan aluminium eksturisi selain PT Sinar Harapan, PT Superex Raya dan PT Indotecno Multi Industries (Sumber: www.kemenperin.go.id, diakses pukul 22.08 WIB, 27 September 2014).

PT Indo-Extrusions adalah perusahaan alumunium ekstrusi yang berdiri sejak tahun 1972 yang berlokasi di Kota Cimahi. Perusahaan ini mengolah alumunium ekstrusi ke dalam beberapa kebutuhan sehari-hari seperti kusen, perahu, kursi, parabola, jendela kereta api, elektronik, karoseri, atap dan lain-lain.

Dalam memenuhi kebutuhan alumunium ekstrusi di Indonesia, pihak manajemen PT Indo-Extrusions melakukan pengontrolan perkembangan perusahaan berupa pengukuran kinerja perusahaan. Total penjualan yang dilakukan setiap tahun dijadikan acuan sebagai alat ukur kinerja perusahaan. Berikut data kinerja perusahaan PT Indo-Extrusions pada Gambar 1

\section{GAMBAR 1 \\ KINERJA PERUSAHAAN PT INDO- EXTRUSIONS CIMAHI TAHUN 2011-2014}

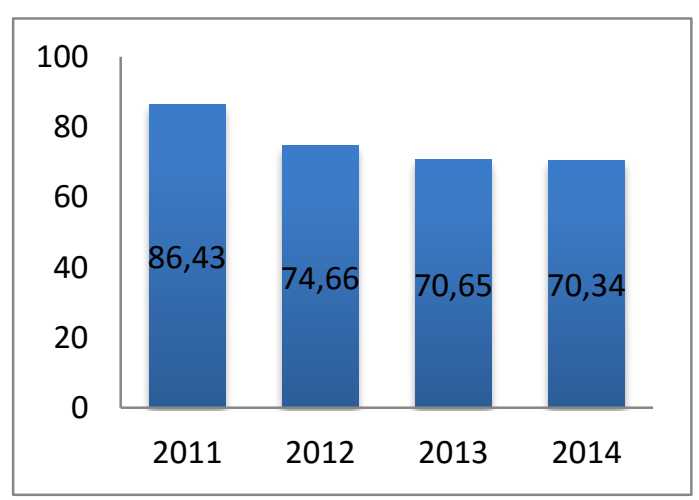

Sumber: Kepala Personalia PT Indo-Extrusions Cimahi (2015)

Berdasarkan Gambar 1 kinerja perusahaan PT Indo-Extrusions pada tahun 2011 mencapai $86,43 \%$, jumlah ini menurun sebesar $11,77 \%$ di tahun 2012 menjadi $74,66 \%$. Kemudian dari tahun 2012-2013 mengalami penurunan sebesar $4,01 \%$ menjadi $70,65 \%$ dan tahun dari tahun 2013-2014 mengalami penurunan sebesar $0,31 \%$ menjadi $70,34 \%$.
Kinerja perusahaan PT Indo-Extrusions mengalami penurunan yang signifikan setiap tahunnya. Sesuai dengan hasil wawancara dengan Bapak Asep Sapeul selaku Kepala Personalia PT Indo-Extrusions, pada tanggal 10 September 2014, pukul 10.25 WIB, hal tersebut dikarenakan tingkat kuantitas produksi yang rendah sehingga menyebabkan menurunnya penjualan.

Dalam mengatasi penurunan kinerja perusahaan yang rendah diperlukan sumber daya manusia yang berkualitas. Karena sumber daya manusia merupakan penggerak kemajuan dari suatu perusahaan. Oleh karena itu PT IndoExtrusions diharapkan memiliki karyawan yang tingkat kinerjanya tinggi.

Sebagai perusahaan yang memenuhi kebutuhan aluminium di Indonesia yang mencapai 600-800 ribu ton per tahun, PT IndoExtrusions memiliki 89 orang karyawan yang dibagi kedalam 2 divisi dengan jumlah karyawan divisi produksi 75 orang dan 14 orang staff. Karyawan divisi produksi merupakan karyawan yang terdiri dari berbagai jenis golongan baik karyawan tetap, karyawan kontrak tahunan, bulanan, borongan dan juga buruh lepas harian. Jumlah karyawan divisi produksi yang lebih banyak dari karyawan staff memicu tingginya tingkat permasalahan di dalam perusahaan, hal tersebut dikarenakan berbagai faktor seperti pendidikan, kompetensi karyawan, beban kerja, dan lain-lain. Rendahnya kinerja karyawan dapat terlihat dari data penilaian kinerja karyawan.

\section{TABEL 1}

REKAPITULASI PENILAIAN KINERJA KARYAWAN TETAP DIVISI PRODUKSI PT INDO-EXTRUSIONS TAHUN 2011-2014

\begin{tabular}{|l|l|l|l|l|}
\hline Tahun & $\begin{array}{l}\text { Jumlah } \\
\text { pegawai }\end{array}$ & $\begin{array}{l}\text { Total } \\
\text { poin }\end{array}$ & $\begin{array}{l}\text { Rata- } \\
\text { rata } \\
(\%)\end{array}$ & Kriteria \\
\hline 2011 & 58 & 4733 & 81,60 & Cukup \\
\hline 2012 & 58 & 4841 & 83,46 & Cukup \\
\hline 2013 & 59 & 4912 & 83,25 & Cukup \\
\hline 2014 & 57 & 4575 & 80,26 & Cukup \\
\hline
\end{tabular}

Sumber : Kepala Personalia PT Indo-Extrusions (2015)

Berdasarkan Tabel 1 kinerja karyawan tetap setiap tahunnya berada pada kriteria cukup. Pada tahun 2011 rata-rata kinerja karyawan mencapai $81,60 \%$ dan mengalami peningkatan sebesar $1,86 \%$ pada tahun 2012 menjadi 83,46\%. Namun pada tahun 2013 kinerja karyawan mengalami penurunan sebesar $0,21 \%$ menjadi 83,25 dan menurun lagi sebesar 2,99\% pada tahun 2014 menjadi $80,26 \%$. 
TABEL 2

REKAPITULASI PENILAIAN KINERJA

KARYAWAN TIDAK TETAP DIVISI PRODUKSI PT INDO-EXTRUSIONS TAHUN 2011-2014

\begin{tabular}{|l|l|l|l|l|}
\hline Tahun & $\begin{array}{l}\text { Jumlah } \\
\text { pegawai }\end{array}$ & $\begin{array}{l}\text { Total } \\
\text { poin }\end{array}$ & $\begin{array}{l}\text { Rata- } \\
\text { rata } \\
(\boldsymbol{\%})\end{array}$ & Kriteria \\
\hline 2011 & 20 & 1577 & 78,85 & Cukup \\
\hline 2012 & 22 & 1615 & 73,40 & Kurang \\
\hline 2013 & 23 & 1675 & 72,82 & Kurang \\
\hline 2014 & 18 & 1325 & 73,61 & Kurang \\
\hline
\end{tabular}

Sumber : Kepala Personalia PT Indo-Extrusions (2015)

Berdasarkan Tabel 2 kinerja karyawan tidak tetap sebagian besar berada pada kriteria kurang. Pada tahun 2011 rata-rata kinerja karyawan sempat mencapai kriteria cukup yaitu $78,85 \%$. Jumlah ini menurun sebesar $5,45 \%$ pada tahun 2012 menjadi $73,40 \%$ dan pada tahun 2013 menurun sebesar $0,58 \%$ menjadi $72,82 \%$. Kemudian pada tahun 2014 mengalami peningkatan sebesar $0,79 \%$ menjadi $73,61 \%$.

Berdasarkan Tabel 1 dan Tabel 2 tentang penilaian kinerja karyawan, rata-rata kinerja karyawan belum optimal. Kinerja karyawan tetap setiap tahunnya berada pada kriteria cukup sedangkan kinerja karyawan tidak tetap cenderung berada pada kriteria kurang. Sesuai dengan hasil wawancara pada tanggal 29 Januari 2015 dengan Bapak Indra Kusuma selaku Kepala Personalia PT Indo-Extrusions rata-rata kinerja tersebut belum mencapai target perusahaan yaitu minimal mencapai kriteria Baik dengan poin rata-rata minimal $85 \%$. Berikut tabel kriteria penilaian kinerja karyawan PT Indo-Extrusions.

TABEL 3

KRITERIA PENILAIAN KINERJA KARYAWAN DIVISI PRODUKSI PT INDOEXTRUSIONS

\begin{tabular}{|l|l|l|l|}
\hline NO & $\begin{array}{l}\text { POIN RATA } \\
\text { RATA }(\boldsymbol{\%})\end{array}$ & KATEGORI & KRITERIA \\
\hline 1 & $95-100$ & A & Sangat Baik \\
\hline 2 & $85-95$ & B & Baik \\
\hline 3 & $75-85$ & C & Cukup \\
\hline 4 & $65-75$ & D & Kurang
\end{tabular}

Sumber: Kepala Personalia PT IndoExtrusions (2015)

Indikasi lain yang menunjukkan kinerja karyawan rendah dapat dilihat dari persentase hasil produksi yang tidak memenuhi target yang telah ditentukan perusahaan. Berikut data target perusahaan beserta persentase ketercapaian target produksi pada Tabel 4
TABEL 4

DATA PERSENTASE KETERCAPAIAN TARGET PRODUKSI PT INDO-EXTRUSIONS PERIODE 20112014

\begin{tabular}{|c|c|c|c|c|c|}
\hline \multirow[b]{2}{*}{$\begin{array}{l}\text { TA } \\
\text { HU } \\
\text { N }\end{array}$} & \multicolumn{2}{|c|}{ PRODUKSI } & \multicolumn{3}{|c|}{ PENYIMPANGAN } \\
\hline & $\begin{array}{c}\text { TARG } \\
\text { ET } \\
\text { PROD } \\
\text { UKSI } \\
\text { EXTR } \\
\text { USI } \\
\text { (KG) }\end{array}$ & $\begin{array}{c}\text { HASIL } \\
\text { PROD } \\
\text { UKSI } \\
\text { EXTR } \\
\text { USI } \\
\text { (KG) }\end{array}$ & $\begin{array}{c}\text { SELI } \\
\text { SIH } \\
\text { (KG) }\end{array}$ & $\begin{array}{c}\text { PERSE } \\
\text { NTASE } \\
(\%)\end{array}$ & $\begin{array}{c}\text { BATAS } \\
\text { TOLE } \\
\text { RANSI } \\
(\%)\end{array}$ \\
\hline 2011 & 400000 & $\begin{array}{l}330676 \\
8\end{array}$ & $\begin{array}{l}6932 \\
3,2\end{array}$ & $17,33 \%$ & $20 \%$ \\
\hline 2012 & 400000 & $\begin{array}{l}295267 \\
, 2\end{array}$ & $\begin{array}{l}1047 \\
32,8\end{array}$ & $26,18 \%$ & $20 \%$ \\
\hline 2013 & 400000 & $\begin{array}{l}294392 \\
, 4\end{array}$ & $\begin{array}{l}1056 \\
07,6\end{array}$ & $26,40 \%$ & $20 \%$ \\
\hline 2014 & 400000 & 281520 & $\begin{array}{l}1184 \\
80,0\end{array}$ & $29.62 \%$ & $20 \%$ \\
\hline
\end{tabular}

Sumber : Kepala Produksi PT Indo-Extrusions Cimahi (2015)

Berdasarkan Tabel 4 terlihat bahwa persentase ketercapaian produksi mengalami penurunan yang signifikan. Pada tahun 20112012 mengalami penurunan sebesar $8,85 \%$, kemudian pada tahun 2012-2013 mengalami penurunan sebesar $0,22 \%$ dan pada tahun 20132014 mengalami penurunan sebesar 3,22\%. Hasil produksi pada tahun 2011-2014 tidak pernah mencapai target produksi yang telah ditentukan oleh perusahaan bahkan melebihi batas toleransi perusahaan. Hal tersebut dapat menimbulkan kerugian bagi perusahaan dan berdampak pada rendahnya kinerja perusahaan.

Sumber daya manusia adalah faktor utama yang mempengaruhi kinerja perusahaan. Sumber daya manusia berperan aktif dan dominan dalam setiap kegiatan perusahaan karena manusia sebagai perencana, pelaku serta penentu terwujudnya tujuan perusahaan. PT Indo-Extrusions dituntut untuk memiliki sumber daya manusia yang kompeten dan berkualitas dengan tingkat kinerja yang tinggi. Sehingga dengan kinerja yang tinggi produktivitas kerja karyawan akan tinggi pula.

Kinerja karyawan merupakan salah satu faktor yang mempengaruhi keberhasilan perusahaan dalam mencapai tujuan. Rendahnya kinerja karyawan mengakibatkan perusahaan tidak dapat mencapai target yang telah ditentukan. Hal ini penting bagi perusahaan untuk terus melakukan persaingan bisnis dalam industri aluminium ekstrusi. Penggunaan tenaga kerja yang efektif dan terarah merupakan kunci kearah peningkatan kinerja karyawan sehingga dibutuhkan suatu kebijakan perusahaan untuk penggerak karyawan agar mau bekerja lebih produktif sesuai dengan rencana yang telah 
ditetapkan. Jadi sesudah karyawan direkrut, dipilih dan dilantik selanjutnya dikembangkan agar lebih sesuai dengan pekerjaan dalam perusahaan.

Berdasarkan hasil wawancara dengan Bapak Yonna R. H selaku Kepala Produksi PT Indo-Ektrusions pada tanggal 10 September 2014, mengatakan bahwa adanya pemborosan bahan baku pada saat proses produksi yang mengakibatkan pembengkakan biaya bahan baku yang berdampak pada rendahnya kinerja perusahaan. Dalam upaya mengurangi pemborosan tersebut perusahaan berusaha meningkatkan kualitas karyawannya dengan melakukan pelatihan.

Dalam penelitian Wijonarko (2012) menegaskan pentingnya menganggap karyawan sebagai aset. Dengan memperlakukan karyawan sebagai aset, otomatis ada peningkatan Individual Capacity dan Organizational Competitiveness, selain itu Peningkatan Kinerja dan Employee Engagement dipastikan didapat (Sumber:

http://www.kabarbisnis.com/read/2833544).

Kemudian berdasarkan penelitian yang dilakukan oleh Raymond (2010) untuk memecahkan masalah terkait dengan peningkatkan kinerja karyawan ada beberapa kemungkinan yang dapat dilakukan oleh perusahaan antara lain melalui pelatihan kerja dan pemberian motivasi.

Pelatihan merupakan proses untuk meningkatkan pengetahuan dan keterampilan karyawan yang dapat mempengaruhi kinerja karyawan. Kegiatan pelatihan memberikan keuntungan kepada karyawan dan perusahaan, berupa keahlian dan keterampilan karyawan yang selanjutnya akan menjadi aset yang berharga bagi perusahaan. Dengan pelaksanaan pelatihan yang tepat, maka perusahaan diharapkan dapat memperbaiki kualitas kerja karyawan dalam mencapai tujuan perusahaan.

Berdasarkan hasil wawancara dengan Bapak Indra Kusuma selaku Kepala Personalia PT Indo-Extrusions pada tanggal 10 September 2014, mengatakan bahwa jenis pelatihan yang diberikan perusahaan kepada karyawan adalah skill Training.

Selain mengadakan pelatihan bagi karyawan, motivasi kerja juga merupakan salah satu faktor yang dapat mempengaruhi kinerja karyawan. Diberikannya motivasi kepada karyawan atau seseorang mempunyai tujuan meningkatkan semangat kerja karyawan dan tanggung jawab karyawan terhadap tugas dan pekerjaannya serta meningkatkan loyalitas dan kestabilan karyawan yang berdampak pada pencapaian tujuan perusahaan.
Menurunnya motivasi kerja karyawan yang mempengaruhi pencapaian tujuan perusahaan disebabkan oleh kejenuhan, dimana karyawan melakukan pekerjaan yang sama berulang-ulang selama masa kerjanya. Hal ini disebabkan karena perusahaan tidak memberikan peluang pengembangan karir (Indra Kusuma, kepala Personalia PT Indo-Extrusions, 10 September 2014)

Menyadari hal ini pihak manajemen PT Indo Extrusions mencoba melakukan perubahan dengan memberi motivasi berupa adanya peluang untuk mengembangkan karir dalam perusahaan. Dengan ini diharapkan motivasi karyawan dalam bekerja dapat meningkat sehingga kinerja perusahaan menjadi optimal.

Pelatihan dan motivasi sangat penting demi meningkatkan kualitas karyawan yang akhirnya dapat mencapai tingkat kinerja karyawan yang optimal. Berdasarkan data dan fenomena yang terjadi dalam perusahaan, maka dalam mengantisipasi masalah yang ada PT Indo-Extrusions membutuhkan upaya peningkatan kemampuan karyawan dengan pelatihan dan peningkatan motivasi karyawan supaya proses atau kegiatan bekerja organisasi menjadi lebih baik.

Berdasarkan uraian latar belakang penelitian maka peneliti memandang perlu untuk melakukan penelitian yang berjudul "Pengaruh Pelatihan dan Motivasi terhadap Kinerja Karyawan PT Indo-Extrusions Cimahi”.

Adapun tujuan dari penelitian ini adalah untuk memperoleh hasil temuan mengenai: 1) Pelatihan yang diterapkan PT Indo-Extrusions, 2) Motivasi kerja karyawan PT Indo-Extrusions, 3) Kinerja karyawan PT Indo-Extrusions, 4) Besarnya pengaruh pelatihan terhadap kinerja karyawan PT Indo-Extrusions, 5) Besarnya pengaruh motivasi kerja terhadap kinerja karyawan PT Indo-Extrusions, 6) Besarnya pengaruh pelatihan dan motivasi kerja terhadap kinerja karyawan PT Indo-Extrusions.

\section{KAJIAN PUSTAKA}

Pendekatan yang digunakan dalam penelitian ini adalah Manajemen Sumber Daya Manusia. Menurut Rivai dan Sagala (2010:1) manajemen sumber daya manusia merupakan salah satu bidang dari manajemen umum yang meliputi segi-segi perencanaan, pengorganisasian, pelaksanaan dan pengendalian. Proses ini terdapat dalam fungsi/bidang produksi, pemasaran, keuangan maupun kepegawaian. Manajemen sumber daya manusia merupakan suatu perencanaan, pengorganisasian, pengkoordinasian, 
pelaksanaan, dan pengawasan terhadap pengadaan, pengembangan, pemberian balas jasa, pengintegrasian, pemeliharaan, dan pemisahan tenaga kerja dalam rangka mencapai tujuan organisasi. (Mangkunegara, 2012:2).

Sumber daya manusia merupakan faktor utama dalam suatu organisasi. Sumber daya manusia yang terdapat di perusahaan perlu dikelola secara profesional agar terwujudnya keseimbangan antara kebutuhan pegawai dengan tuntutan dan kemampuan organisasi perusahaan. Manajemen sumber daya manusia mempunyai tugas untuk mengelola sumber daya manusia sebaik mungkin agar tercapainya tujuan yang telah ditetapkan perusahaan. Adapun fungsifugsi manajemen sumber daya manusia, menurut Rivai dan Sagala (2010:13) yaitu Fungsi manajerial yang terdiri dari perencanaan (planning), pengorganisasian (organizing), pengarahan (directing), pengendalian (controlling). Fungsi operasional yang terdiri dari pengadaan tenaga kerja (SDM), pengembangan, kompensasi, pengintegrasian, pemeliharaan, pemutusan hubungan kerja.

Aspek lain dari peranan manajemen sumber daya manusia adalah peranannya dalam pencapaian tujuan perusahaan secara terpadu. Manajemen sumber daya manusia tidak hanya memperhatikan kepentingan perusahaan, tetapi juga memperhatikan kebutuhan karyawan dan pemilik tuntutan masyarakat luas. Peranan manajemen sumber daya manusia adalah mempertemukan ketiga kepentingan tersebut yaitu perusahaan, karyawan, dan masyarakat luas menuju tercapainya efektivitas, efisiensi, produktivitas dan kinerja perusahaan.

Pelatihan merupakan salah satu kebutuhan karyawan yang harus dipenuhi. Pelatihan masuk ke dalam fungsi operasional pengembangan. Seperti yang diakatakan Sedarmayanti (2010:163) bahwa pengembangan SDM dilakukan melalui peningkatan kemampuan karyawan dengan cara menambah pengetahuan, keterampilan dan sikap. Hal ini dapat dilakukan dengan memberikan pelatihan kepada karyawan

Hal ini sesuai dengan Zahra, Iram dan Naeem (2014:60) yang menyatakan bahwa "Pelatihan merupakan kegiatan penting untuk memiliki tenaga kerja yang berkualitas baik, fleksibel dan siap untuk mencapai standar yang lebih tinggi dari kinerja". Kemudian didukung oleh penelitian yang dilakukan oleh Oroni, Iravo dan Elijah (2014:40) yang menyatakan bahwa "Pelatihan dapat meningkatkan efisiensi dan efektivitas kinerja karyawan".

Selanjutnya Zahra, Iram dan Naeem (2014:60) menyatakan Pelatihan merupakan kegiatan penting untuk memiliki tenaga kerja yang berkualitas baik, fleksibel dan siap untuk mencapai standar yang lebih tinggi dari kinerja. Sedangkan Noe et al dalam Steffenny dan Praptiningsih (2013:2) menyatakan bahwa Pelatihan adalah upaya yang direncanakan untuk memfasilitasi pembelajaran keterampilan berhubungan dengan pekerjaan, pengetahuan, dan perilaku oleh karyawan

$$
\text { Rivai dan Sagala (2010:211) }
$$
menyatakan bahwa pelatihan adalah bagian pendidikan yang menyangkut proses belajar untuk memperoleh dan meningkatkan keterampilan di luar sistem pendidikan yang berlaku dalam waktu yang relative singkat dengan metode yang lebih mengutamakan praktik daripada teori. Kemudian Rivai dan Sagala mengemukakan enam dimensi dari pelatihan, yaitu instruktur, peserta, materi (bahan), metode, tujuan pelatihan dan lingkungan yang menunjang. Dimensi pelatihan ini merupakan dimensi pelatihan yang digunakan dalam penelitian ini.

Selain pelatihan, motivasi juga merupakan salah satu fungsi operasional pengintegrasian yang penting. Motivasi merupakan dorongan dari dalam atau luar diri seseorang untuk bertindak. Apabila motivasi seseorang positif maka hasilnya akan positif juga dan sebaliknya.

Colquit, LePine dan Wesson mengatakan bahwa "Motivation as a set of energetic force that starts from both inside and outside workers, starting from the business associated with the work, and consider the direction, intensity and persistence". Perkataan diatas dapat diartikan bahwa Motivasi sebagai sekumpulan kekuatan energik yang dimulai baik dari dalam maupun diluar pekerja, dimulai dari usaha yang berkaitan dengan pekerjaan, dan mempertimbangkan arah, intensitas dan ketekunannya.

$$
\text { Mahbub Sharfaraj (2014:10) }
$$

menjelaskan bahwa "Motivation is the mental force, which makes an individual willing to carryout his duties and responsibilities for the achievement of the goals of his organization". Dari perkataan Mahbub Sharfaraj dapat diartikan bahwa motivasi adalah kekuatan mental, yang membuat seorang individu bersedia untuk melaksanakan tugas dan tanggung jawabnya untuk pencapaian tujuan organisasinya.

Hal ini sejalan dengan penelitian yang dilakukan oleh Agusta dan Sutanto (2013) yang menyatakan bahwa "Motivasi kerja berpengaruh positif dan signifikan terhadap kinerja karyawan". Adapun indikator dari motivasi menurut McClelland dalam Newstrom 
(2011:111) yaitu need for achievement, need for power dan need for affiliation.

Pelatihan dan motivasi kerja yang tepat akan berdampak pada peningkatan kinerja karyawan sehingga produktivitas perusahaan dapat optimal sesuai dengan tujuan perusahaan. Berdasarkan penjelasan teori di atas, dapat dibuat paradigma penelitian yang menghubungkan antara penerapan pelatihan dan motivasi kerja serta pengaruhnya terhadap kinerja karyawan seperti berikut ini:

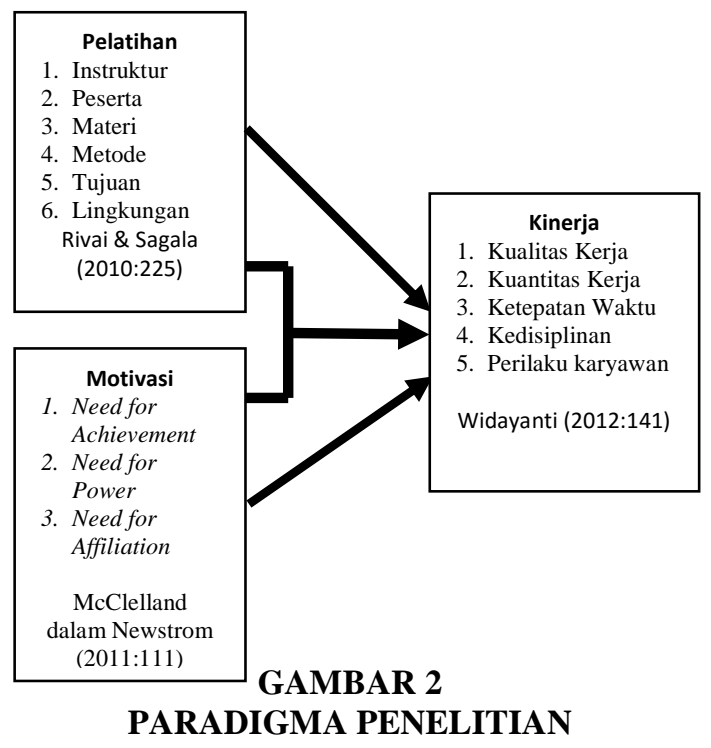

\section{METODELOGI PENELITIAN}

Objek penelitian ini adalah Pelatihan sebagai variabel bebas (independent variable) $\left(X_{1}\right)$, motivasi kerja sebagai variabel bebas (independent variable) $\left(X_{2}\right)$ dan kinerja karyawan sebagai variabel terikat (dependent variable) (Y). Pelatihan $\left(X_{1}\right)$ memiliki dimensi yaitu instruktur, peserta, materi, metode, tujuan, dan lingkungan. Motivasi Kerja $\left(X_{2}\right)$ memiliki dimensi yaitu Need for Achievement, Need for Power dan Need for Affiliation. Penelitian ini dilakukan di salah satu perusahaan yang bergerak dalam bidang pengolahan alumunium, yaitu PT Indo-Extrusions yang berlokasi di Jl. Leuwigajah No. 134 Cimahi.

Jenis penelitian ini adalah penelitian deskriptif dan verifikatif. Penelitian ini dapat mengetahui bagaimana pengaruh Pelatihan dan motivasi kerja terhadap kinerja karyawan PT Indo-Extrusions Cimahi. Penelitian deskriptif bertujuan untuk memperoleh gambaran mengenai pengaruh Pelatihan dan motivasi kerja terhadap kinerja karyawan PT Indo-Extrusions Cimahi. Berdasarkan jenis penelitian di atas maka dilakukan pengumpulan data di lapangan. Metode yang digunakan dalam penelitian ini adalah explanatory survey. Populasi dalam penelitian ini yakni karyawan Divisi Produksi PT Indo-Extrusions Cimahi yaitu sebanyak 75 orang. Pengambilan sampel dikarenakan populasi kurang dari 100 orang, maka sampel yang diambil adalah seluruh jumlah populasi karyawan.

Secara statistik, hipotesis yang akan diuji dalam rangka pengambilan keputusan penerimaan atau penolakan hipotesis dapat dirumuskan sebagai berikut:

1. Hipotesis 1

$\mathrm{H}_{\mathrm{o}}: p<0$, artinya tidak terdapat pengaruh positif dari pelatihan terhadap kinerja karyawan.

$\mathrm{H}_{\mathrm{a}}: p>0$, artinya terdapat pengaruh positif dari pelatihan terhadap kinerja karyawan.

2. Hipotesis 2

$\mathrm{H}_{\mathrm{o}}: p<0$, artinya tidak terdapat pengaruh positif dari motivasi kerja terhadap kinerja karyawan.

$\mathrm{H}_{\mathrm{a}}: p>0$, artinya terdapat pengaruh positif dari motivasi kerja terhadap kinerja karyawan.

3. Hipotesis 3

$\mathrm{H}_{\mathrm{o}}: p<0$, artinya tidak terdapat pengaruh positif dari pelatihan dan motivasi kerja terhadap kinerja karyawan.

$\mathrm{H}_{\mathrm{a}}: p>0$, artinya terdapat pengaruh positif dari pelatihan dan motivasi kerja terhadap kinerja karyawan.

\section{HASIL PENELITIAN DAN PEMBAHASAN}

1. Pembahasan Deskriptif

A. Tanggapan Karyawan

a. Pelatihan

Berdasarkan hasil penelitian yang bersifat empirik mengenai pelaksanaan pelatihan di PT. Indo-Extrusions Cimahi, dihasilkan temuan bahwa instruktur pelatihan memberikan kontribusi yang cukup tinggi bagi karyawan dalam mencapai keberhasilan pelaksanaan pelatihan.

\section{b. Motivasi Kerja}

Berdasarkan hasil penelitian yang bersifat empirik mengenai motivasi kerja pada PT IndoExtrusions Cimahi, dihasilkan temuan bahwa motivasi kerja di PT. Indo-Extrusions Cimahi baik, hal ini dilihat dari dimensi kebutuhan beraffiliasi (need for affiliation) yang telah memberikan kontribusi yang cukup tinggi bagi karyawan dalam mencapai motivasi kerja.

\section{c. Kinerja Karyawan}

Berdasarkan hasil penelitian yang bersifat empirik mengenai kinerja karyawan pada PT Indo-Extrusions Cimahi, dihasilkan temuan bahwa kinerja karyawan di PT Indo-Extrusions Cimahi baik, hal ini dilihat dari dimensi kualitas kerja yang telah memberikan kontribusi yang cukup tinggi dalam mencapai kinerja karyawan. 


\section{Pembahasan Verifikatif}

Dengan menggunakan program SPSS 21.0 for Windows, diperoleh hasil koefisien regresi sebagai berikut:

TABEL 5

\section{MODEL REGRESI LINEAR BERGANDA PELATIHAN DAN MOTIVASI KERJA TERHADAP KINERJA KARYAWAN Coefficients $^{\mathrm{a}}$}

\begin{tabular}{|c|c|c|c|c|c|}
\hline \multirow[t]{2}{*}{ Model } & \multicolumn{2}{|c|}{$\begin{array}{l}\text { Unstandar } \\
\text { dized } \\
\text { Coefficien } \\
\text { ts }\end{array}$} & $\begin{array}{l}\text { Standard } \\
\text { ized } \\
\text { Coeffici } \\
\text { ents }\end{array}$ & $\mathrm{t}$ & Sig \\
\hline & B & $\begin{array}{l}\text { Std } \\
\text { Err } \\
\text { or }\end{array}$ & Beta & & \\
\hline (Constant) & 7.083 & $\begin{array}{r}3.9 \\
44\end{array}$ & & $\begin{array}{r}1.79 \\
6\end{array}$ & $\begin{array}{r}.07 \\
7\end{array}$ \\
\hline 1 Pelatihan & .310 & $\begin{array}{r}.06 \\
2\end{array}$ & .444 & $\begin{array}{r}4.98 \\
0\end{array}$ & $\begin{array}{r}.00 \\
0\end{array}$ \\
\hline $\begin{array}{l}\text { Moitvasi } \\
\text { Kerja }\end{array}$ & .706 & $\begin{array}{r}.12 \\
1\end{array}$ & .520 & $\begin{array}{r}5.83 \\
0\end{array}$ & $\begin{array}{r}.00 \\
0\end{array}$ \\
\hline
\end{tabular}

a. Dependent Variable: Kinerja

Sumber: Hasil Pengolahan Data 2015

$$
Y=7,083+0,310 X_{1}+0,706 X_{2}
$$

Berdasarkan persamaan regresi linear berganda di atas, konstanta sebesar 7,083 menyatakan bahwa jika tidak ada pelatihan dan motivasi kerja, maka besarnya kinerja karyawan sebesar 7,083 . Koefisien regresi 0,310 satu satuan nilai artinya setiap terjadi peningkatan pelatihan akan meningkatkan kinerja sebesar 0,310 satu satuan nilai dan sebaliknya jika terjadi penurunan kinerja, pelatihan akan menurunkan kinerja sebesar 0,310 satu satuan nilai. Sedangkan koefisien regresi 0,706 satu satuan nilai artinya setiap terjadi peningkatan motivasi kerja akan meningkatkan kinerja sebesar 0,706 satu satuan nilai dan sebaliknya jika terjadi penurunan kinerja, motivasi kerja akan menurunkan kinerja 0,706 satu satuan nilai.

Hubungan antara pelatihan dan moitvasi kerja terhadap kinerja karyawan diperoleh dari model summary yang dijelaskan secara rinci berikut:

TABEL 6

OUTPUT KOEFISIEN DETERMINASI Model Summary ${ }^{\mathrm{b}}$

\begin{tabular}{|l|c|c|c|c|}
\hline $\begin{array}{l}\text { Mode } \\
\mathbf{l}\end{array}$ & $\mathbf{R}$ & $\begin{array}{c}\mathbf{R} \\
\text { Squa } \\
\text { re }\end{array}$ & $\begin{array}{c}\text { Adjusted } \\
\text { R Square }\end{array}$ & $\begin{array}{c}\text { Std. Error } \\
\text { of the } \\
\text { Estimate }\end{array}$ \\
\hline 1 & $\begin{array}{r}.936 \\
\mathrm{a}\end{array}$ & $\mathbf{. 8 7 7}$ & .873 & 3.27953 \\
\hline
\end{tabular}

a. Predictors: (Constant), Motivasi Kerja, Pelatihan b. Dependent Variable: Kinerja

Sumber: Hasil Pengolahan Data 2015

Berikut adalah hasil perhitungan

koefisien determinasi $\square_{1}, \square_{2}$, dan Y:

$\mathrm{KD} \square_{1}$ dan $\square_{2}$ terhadap $\mathrm{Y}=\square^{2} \times 100 \%=$

$(0,936)^{2} \times 100=87,7 \%$

Koefisien determinasi untuk pelatihan $\left(\mathrm{X}_{1}\right)$ dan motivasi kerja $\left(\mathrm{X}_{2}\right)$ terhadap kinerja karyawan (Y) adalah 87,7\%. Dengan kata lain kinerja karyawan dipengaruhi $87,7 \%$ oleh pelatihan dan motivasi kerja, sedangkan 12,3\% dipengaruhi oleh faktor-faktor lainnya yang tidak diteliti dalam penelitian ini.

Adapun besarnya pengaruh secara parsial antara masing-masing variabel dapat dilihat pada Tabel 4 dari standardized coefficient (BETA) yaitu pelatihan terhadap kinerja karyawan mempunyai pengaruh sebesar 0,444, artinya kinerja karyawan dipengaruhi pelatihan sebesar $44,4 \%$ dan sisanya $55,6 \%$ dipengaruhi oleh faktor lainnya yang tidak diteliti dalam penelitian ini. Motivasi kerja terhadap kinerja karyawan mempunyai pengaruh sebesar 0,520, yang artinya kinerja karyawan dipengaruhi motivasi kerja sebesar $52 \%$ dan sisanya $48 \%$ dipengaruhi oleh faktor lain. Berdasarkan paparan di atas berikut pengaruh pelatihan dan motivasi kerja terhadap kinerja karyawan PT Indo-Extrusions pada Gambar 3 berikut ini:

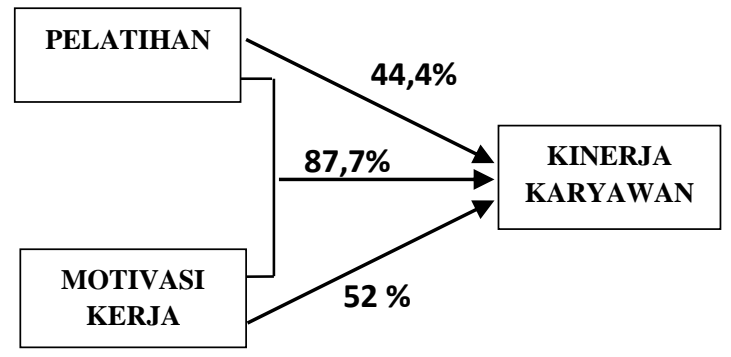

Sumber: Hasil Pengolahan Data 2015

GAMBAR 3

Pengaruh Pelatihan dan Motivasi Kerja Terhadap Kinerja Karyawan

Uji Hipotesis 
TABEL 7

NILAI SIGNIFIKANSI UJI F

ANOVA $^{\mathrm{a}}$

\begin{tabular}{|c|c|c|c|c|c|}
\hline Model & $\begin{array}{c}\text { Sum of } \\
\text { Square } \\
\text { s }\end{array}$ & $\mathrm{df}$ & $\begin{array}{l}\text { Mean } \\
\text { Square }\end{array}$ & $\mathrm{F}$ & Sig. \\
\hline $\begin{array}{cc} & \begin{array}{c}\text { Regressi } \\
\text { on }\end{array} \\
1 & \text { Residual } \\
& \text { Total }\end{array}$ & $\begin{array}{c}5498.2 \\
04 \\
774.38 \\
3 \\
6272.5 \\
87\end{array}$ & $\begin{array}{c}2 \\
72 \\
74\end{array}$ & $\begin{array}{c}2749.10 \\
2 \\
10.755\end{array}$ & $\begin{array}{c}255.60 \\
4\end{array}$ & $.000^{\mathrm{b}}$ \\
\hline
\end{tabular}

a. Dependent Variable: Kinerja

b. Predictors: (Constant), Motivasi Kerja, Pelatihan

Sumber: Hasil Pengolahan Data 2015

Tabel 7 menunjukan pengujian untuk uji $\mathrm{F}$ yang diambil dari Anova dengan tingkat probabilitas $(\mathrm{Sig})=0,000$, maka taraf signifikan 0,05 yaitu $0,000 \leq 0,05$. maka keputusan adalah $\mathrm{H}_{\mathrm{o}}$ ditolak. Artinya terdapat pengaruh yang positif antara pengaruh pelatihan dan motivasi kerja terhadap kinerja karyawan PT IndoExtrusions.

Peneliti juga melakukan pengujian pengaruh variabel bebas secara bersama-sama terhadap variabel terikat dengan menggunakan uji $\mathrm{F}$ yaitu $F_{\text {hitung }}>F_{\text {tabel }}$. Maka $F_{\text {tabel }}$ dengan 75 responden yaitu pada $a=0,05$ adalah 3,124 . Sehingga didapat $255.604>3,122$, maka $\mathrm{H}_{\mathrm{o}}$ ditolak. Kesimpulannya sama dengan pengujian yang dilakukan dengan menggunakan nilai probabilitas. Dengan demikian dapat disimpulkan bahwa hipotesis dalam penelitian ini yaitu $\mathrm{H}_{\mathrm{o}}$ ditolak dan $\mathrm{H}_{\mathrm{a}}$ diterima, sehingga:

1. Terdapat pengaruh positif dari pelatihan terhadap kinerja karyawan PT IndoExtrusions di Cimahi

2. Terdapat pengaruh positif dari motivasi kerja terhadap kinerja karyawan PT Indo-Extrusions di Cimahi

3. Terdapat pengaruh positif dari pelatihan dan motivasi kerja terhadap kinerja karyawan PT Indo-Extrusions di Cimahi

\section{KESIMPULAN DAN REKOMENDASI}

\section{KESIMPULAN}

1. Hasil penelitian menyatakan bahwa, Pelatihan pada PT Indo-Extrusions Cimahi berada pada kategori baik. Hal ini menunjukkan bahwa Pelatihan PT IndoExtrusions Cimahi sudah baik. Dimensi yang memiliki penilaian paling tinggi yaitu instruktur pelatihan dengan perolehan skor 1230 atau sebesar $78,10 \%$ sedangkan dimensi lingkungan pelatihan yang memiliki penilaian paling rendah yaitu dengan perolehan skor 1143 atau sebesar 72,57\%.

2. Hasil penelitian menyatakan bahwa, motivasi kerja karyawan pada PT IndoExtrusions Cimahi berada pada ketegori baik. Hal ini menujukkan bahwa motivasi kerja karyawan PT Indo-Extrusions Cimahi sudah baik. Dimensi yang memiliki penilaian paling tinggi yaitu kebutuhan beraffiliasi (need for affiliation) dengan perolehan skor 1671 atau sebesar $78,90 \%$ sedangkan dimensi yang memiliki penilaian paling rendah yaitu kebutuhan berprestasi (need for achievement) dan kebutuhan kekuasaaan (need for power) dengan perolehan skor 1657 atau sebesar 78,90\%.

3. Hasil penelitian menyatakan bahwa, kinerja karyawan PT Indo-Extrusions Cimahi berada pada ketegori tinggi. Hal ini menunjukkan bahwa kinerja karyawan PT Indo-Extrusions Cimahi sudah baik. Dimensi yang memiliki penilaian paling tinggi yaitu kualitas kerja dengan perolehan skor 1324 atau sebesar $84.06 \%$ sedangkan dimensi yang memiliki penilaian paling rendah yaitu perilaku karyawan dengan perolehan skor 1154 atau sebesar 73,27\%.

4. Hasil penelitian menyatakan bahwa pelatihan mempunyai pengaruh positif terhadap kinerja karyawan dengan pengaruh secara langsung sebesar $44,4 \%$. Hal ini menujukan bahwa semakin baik pelaksanaan pelatihan, maka semakin baik pula kinerja karyawan tersebut.

5. Hasil penelitian menyatakan bahwa motivasi kerja mempunyai pengaruh positif terhadap kinerja karyawan dengan pengaruh secara langsung sebesar 52\%. Hal ini menujukan bahwa semakin baik motivasi kerja karyawan, maka semakin baik pula kinerja karyawan tersebut.

6. Hasil penelitian menatakan bahwa, pelatihan dan motivasi kerja memiliki pengaruh positif terhadap kinerja karyawan PT IndoExtrusions dengan pengaruh langsung sebesar $87,7 \%$. Hal ini menunjukkan bahwa semakin baik pelatihan dan motivasi kerja karyawan PT Indo-Extrusions maka akan semakin baik pula kinerja karyawan di PT Indo-Extrusions.

\section{SARAN}

1. Berdasarkan kesimpulan, dimensi lingkungan pelatihan di perusahaan rendah, maka direkomendasikan dilakukan perbaikan dalam hal yang menyangkut fasilitas dalam pelatihan, lingkungan yang mendukung pelatihan serta lingkungan 
pelatihan yang kondusif. Dalam hal ini perusahaan harus memperhatikan lingkungan pelatihan mulai dari pengaturan lay-out peralatan, memperhatikan efektivitas banyaknya peserta terhadap banyaknya instruktur, pencahayaan, ventilasi, serta terhindar dari kebisingan. Apabila lingkungan pelatihan ditingkatkan maka karyawan akan merasa nyaman selama mengikuti pelatihan sehingga karyawan akan lebih memahami materi dalam pelatihan sehingga peningkatan kemampuan dan keterampilan karyawan kemungkinan besar akan tercapai.

2. Berdasarkan kesimpulan dimensi kebutuhan berprestasi rendah, maka direkomendasikan dilakukan perbaikan dalam pemberian motivasi pada karyawan khususnya motivasi untuk berprestasi. Dalam hal ini perusahaan diharapkan lebih memperhatikan hal-hal yang menyangkut pemberian motivasi seperti pemberian penghargaan, bonus dan promosi jabatan kepada karyawan yang berprestasi. Apabila karyawan memiliki motivasi berprestasi yang tinggi maka karyawan akan semakin giat dalam bekerja demi pencapaian prestasi dan penghargaan dari perusahaan.

3. Berdasarkan kesimpulan dimensi perilaku karyawan rendah, maka direkomendasikan dilakukan perbaikan dalam hal berinteraksi atau berkomunikasi dengan lingkungan kerja. Hal ini dapat dilakukan dengan mengadakan gathering rutin bagi karyawan. Kegiatan gathering berfungsi sebagai sarana refreshing, membentuk team work yang solid serta mempererat hubungan antar karyawan. Apabila karyawan dapat berinteraksi dan berkomunikasi dengan baik dengan rekan kerja atau atasannya, maka akan terjalin kerjasama dalam bekerja. Sehingga kinerja karyawan akan meningkat dan tujuan perusahaan dapat dicapai dengan optimal.

4. Hasil penelitian menyatakan bahwa pelatihan berpengaruh positif dan signifikan terhadap kinerja karyawan, maka penulis merekomendasikan agar PT Indo-Extrusions mempertahankan dan lebih meningkatkan program pelatihan di PT Indo-Extrusions.

5. Hasil penelitian menyatakan bahwa motivasi kerja berpengaruh positif dan signifikan terhadap kinerja karyawan, maka penulis merekomendasikan agar PT Indo-Extrusions mempertahankan dan lebih meningkatkan motivasi kerja karyawan di PT IndoExtrusions.
6. Hasil penelitian menyatakan bahwa pelatihan dan motivasi kerja berpengaruh positif dan signifikan terhadap kinerja karyawan, maka penulis merekomendasikan agar PT Indo-Extrusions mempertahankan dan lebih meningkatkan kinerja karyawan dengan cara meningkatkan pelatihan dan motivasi kerja karyawan agar perusahaan memiliki sumber daya manusia yang berkualitas dan unggul demi perkembangan dan kemajuan perusahaan.

\section{DAFTAR PUSTAKA}

Agusta dan Sutanto. 2013. Pengaruh Pelatihan Dan Motivasi Kerja Terhadap Kinerja Karyawan CV Haragon Surabaya. Jurnal Manajemen Bisnis. Vol 1 (3), p. 1-9

Colquitt, Jason A., Jeffery A. LePine, and Michael J. Wesson. 2011. Organizational Behavior. New York: McGraw-Hill

Mangkunegara, A. Anwar Prabu. 2011. Perencanaan dan Pengembangan Sumber Daya Manusia. Bandung: Refika Aditama

Newstrom, Jhon W. 2011. Organizational Behavior, Human Behavior at Work. New York: McGraw-Hill

Oroni, Iravo, Elijah. 2014. Influence of Motivation on Tea Factory Employee Performance in Kenya. A Case of Kisii County, Kenya. Journal of Business and Management. Vol 16 (4) ISSN: 2278-487X PP 36-41

Rivai dan Sagala.2010. Manajemen Sumber Daya Manusia untuk Perusahaan. Jakarta: PT Rajagrafindo Persada

Sedarmayanti. 2009. Sumber Daya Manusia dan Produktivitas Kerja. Cetakan Ketiga. Bandung: CV. Mandar Maju

Sharfaraj, Mahbub. 2014. Effectiveness of NonFinancial Motivation Programs in Domestic and Multinational Pharmaceutical Companies. Journal of Business and Management. Vol 16 (5), ISSN: 2278-487X, p. 27-35

Steffenny dan Praptiningsih. 2013. Analisis Penerapan Human Resource Training And Development dan Efektivitasnya pada PT. Jayamas Mandiri Plus Surabaya. Jurnal Manajemen Bisnis. Vol 1 (3), p.1-9

Widayanti, Rahayu. 2012. Pengaruh Hard Skill dan Soft Skill Terhadap Kinerja Karyawan pada PT Telkom Kandatel Malang. Jurnal Pengembangan 
Journal of Business Management and Enterpreneurship Education | Volume 2, Number 1, April 2016, hal.255-264

Manajemen Informatika dan Komputer. Vol 3 (1) ISSN: 20862652, p. 62-86

Zahra, Iram dan Naeem. 2014. Employee Training and Its Effect on Employees' Job Motivation and Commitment: Developing and Proposing a Conceptual Model. Journal of

Business and Management. Vol 16 (9) ISSN: $2278-487 X$, p. $60-68$ 